\title{
Study on organic matter fractions in the surface microlayer in the Baltic Sea by spectrophotometric and spectrofluorometric methods
}

\author{
Violetta Drozdowska ${ }^{1}$, Iwona Wrobel ${ }^{1}$, Piotr Markuszewski ${ }^{1}$, Przemysław Makuch $^{1}$, Anna Raczkowska ${ }^{2}$, and \\ Piotr Kowalczuk $^{2}$ \\ ${ }^{1}$ Physical Oceanography Department, Institute of Oceanology Polish Academy of Sciences, Sopot, 81-712, Poland \\ ${ }^{2}$ Marine Physics Department, Institute of Oceanology Polish Academy of Sciences, Sopot, 81-712, Poland \\ Correspondence to: Violetta Drozdowska (drozd@iopan.pl)
}

Received: 9 February 2017 - Discussion started: 13 March 2017

Revised: 4 July 2017 - Accepted: 12 July 2017 - Published: 31 August 2017

\begin{abstract}
The fluorescence and absorption measurements of the samples collected from a surface microlayer (SML) and a subsurface layer (SS), at a depth of $1 \mathrm{~m}$, were studied during three research cruises in the Baltic Sea along with hydrophysical studies and meteorological observations. Several absorption $\left(E_{2}: E_{3}, S, S_{\mathrm{R}}\right)$ and fluorescence (fluorescence intensities at Coble classified peaks: $A, C, M, T$ the ratio $(M+T) /(A+C)$, HIX (humification index)) indices of colored and fluorescent dissolved organic matter (CDOM and FDOM) helped to describe the changes in molecular size and weight as well as in composition of organic matter. The investigation allowed the assessment of a decrease in the contribution of two terrestrial components ( $A$ and $C$ ) with increasing salinity $(\sim 1.64$ and $\sim 1.89 \%$ in the SML and $\sim 0.78$ and $\sim 0.71 \%$ in the SS, respectively) and an increase in components produced in situ $(M$ and $T)$ with salinity $(\sim 0.52$ and $\sim 2.83 \%$ in the SML and $\sim 0.98$ and $\sim 1.87 \%$ in the SS, respectively). Hence, a component $T$ reveals the biggest relative changes along the transect from the Vistula River outlet to Gdansk Deep, in both the SML and SS, although an increase was higher in the SML than in the SS ( $\sim 18.5$ and $\sim 12.3 \%$, respectively). The ratio $E_{2}: E_{3}$ points to greater changes in the molecular weight of CDOM affected by a higher rate of photobleaching in the SML. The HIX index reflects a more advanced stage of humification and condensation processes in the SS. Finally, the results reveal a higher rate of degradation processes occurring in the SML than in the SS. Thus, the specific physical properties of surface active organic molecules (surfactants) may modify, in a specific way, the solar light spectrum entering the sea and a penetration depth of the solar radiation. Research on
\end{abstract}

the influence of surfactants on the physical processes linked to the sea surface becomes an important task, especially in coastal waters and in the vicinity of the river mouths.

\section{Introduction}

The sea surface is a highly dynamic interface between the sea and the atmosphere (Soloviev and Lukas, 2006; Liss and Duce, 2005). The physicochemical and biological properties of a surface microlayer (SML, a surface film) are clearly and measurably different from the underlying water due to the molecules forming SML, called surfactants. Sea surface films are created by organic matter from marine and terrestrial sources: (i) dissolved and suspended products of marine plankton contained in seawater (Engel et al., 2017), (ii) terrestrial organic matter transported from land with riverine outflow (natural and synthetic), (iii) natural oil leakages from the sea-bottom, and (iv) various anthropogenic sources that includes discharge of hydrocarbons products from undersea oil and gas production, marine traffic pollution, terrestrial discharge hydrocarbons, and persistent organic pollutants (Cuncliffe et al., 2013; Engel et al., 2017). Surface films dissipate due to loss of material on the sea surface, including microbial degradation, chemical and photochemical processes, as well as due to absorption and adsorption into particulates (Liss et al., 1997). The surface microlayer is almost ubiquitous and covers most of the surface of the ocean, even under high turbulence conditions (Cuncliffe et al., 2013). Surface active molecules present in the SML may modify a number of physical processes occurring in the sur- 
face microlayer: surfactants affect the solar radiation penetration depth (Santos et al., 2012; Carlucci et al., 1985), exchange of momentum between atmosphere and ocean by reducing the sea surface roughness (Nightingale et al., 2000; Frew et al., 1990) and gas exchange between ocean and atmosphere, impacting production of aerosols from the sea surface (Vaishaya et al., 2012; Ostrowska et al., 2015; Petelski et al., 2014). Therefore, research on the influence of surfactants on the sea surface properties becomes an important task, especially in coastal waters and in the vicinity of the river mouths (Maciejewska and Pempkowiak, 2015).

Surfactants comprise a complex mixture of different organic molecules of amphiphilic and aromatic structures (with hydrophobic and/or hydrophilic heads) rich in carbohydrates, polysaccharides, and protein-like and humus (fulvic and humic) substances (Williams et al., 1986; Ćosović and Vojvodić, 1998; Cuncliffe et al, 2011). Some dissolved organic compounds possess, especially fulvic and humic substances, optically active parts of molecules that absorb the light, called chromophores (CDOM, chromophoric dissolved organic matter), and fluorophores, that absorb and emit light (FDOM - fluorescent dissolved organic matter). Due to the complexity and compositional variability of the dissolved organic matter mixture, the absorption and fluorescence (excitation-emission matrix) spectroscopy available methods were found to be as fast and reliable for detection and identification of the dissolved organic matter in seawater (Stedmon et at, 2003; Hudson et al., 2007; Coble, 2007; Jørgensen et al., 2011). Absorption and fluorescence spectra of specific organic compounds groups may allow identification of source transformations of dissolved organic matter (Coble, 1996; Lakowicz, 2006). Several indices describing the changes of a concentration (Blough and Del Vecchio, 2002), a molecular weight (Peuravuori and Pihlaja, 1997), a composition of CDOM or FDOM (Stedmon and Bro, 2008; Boehme and Wells, 2006), and a rate of degradation processes (Milori et al., 2002; Glatzel et al., 2003; Zsolnay, 2003) can be calculated from the CDOM absorption and FDOM fluorescence excitation and emission matrix (EEM) spectra, which could be useful to study dissolved organic matter dynamics and composition in a surface microlayer. Recent advances in applications of the absorption and fluorescence spectroscopy in environmental studies on aquatic dissolved organic matter both in fresh and marine environments and engineered water systems have been summarized in numerous text books and review papers (e.g., Coble, 2007; Hudson et al., 2007; Ishii and Boyer, 2012; Andrade-Eiroa et al., 2013; Nelson and Siegel, 2013; Coble et al., 2014; Stedmon and Nelson, 2015). The humic substances contribute significantly both to the CDOM pool in the water column as well as to surfactant concentrations, especially in coastal ocean, estuaries and semi-enclosed marine basins that are impacted by terrestrial runoff and marine traffic. Therefore optical methods could be used efficiently to determine of natural and anthropogenic organic surface active substances in the SML (Drozdowska et

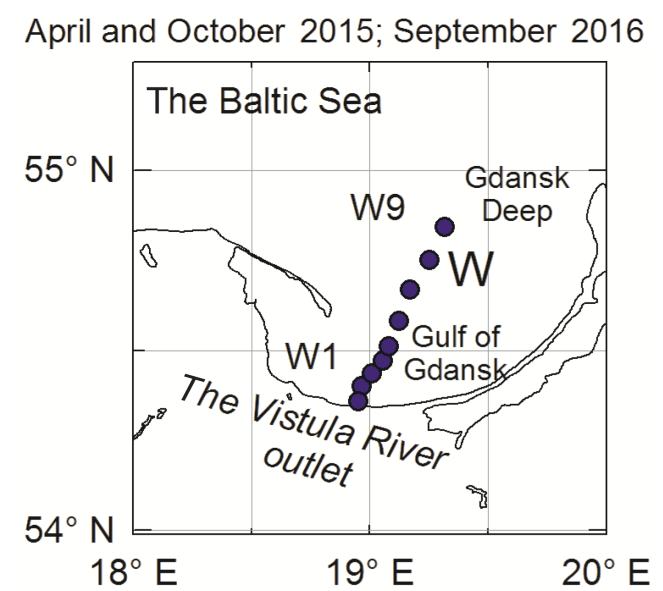

Figure 1. Measurement stations sampled during research cruises of R/V Oceania: 28 April and 15-16 October in 2015 and 11 September in 2016.

al., 2013, 2015; Pereira et al., 2016; Frew et al.,2004; Zhang et al., 2009; McKnight et al., 1997; Guéguen et al., 2007).

The Baltic Sea is a semi-enclosed marine basin with annual riverine discharge reaching ca. $0.5 \times 10^{3} \mathrm{~km}^{3}$ of freshwater (Leppäranta and Myrberg, 2009). Maximum freshwater runoff occurs in April-May. The freshwater carries both high concentrations of CDOM (Drozdowska and Kowalczuk, 1999; Kowalczuk, 1999; Kowalczuk et al., 2010; Ylostallo et al., 2016) and substantial loads of anthropogenic pollutants and inorganic nutrients (Drozdowska et al., 2002; Pastuszak et al., 2012) that stimulate phytoplankton blooms. This marine basin is also impacted by significant pollution caused by the high marine traffic (Konik and Bradtke, 2016). The main goals of this study were (i) to determine the distribution of concentration of specific CDOM and FDOM components in the SML and subsurface (SS - a depth of $1 \mathrm{~m}$ ) waters in the salinity gradient along a transect from the Vistula River mouth to Gdansk Deep, Gulf of Gdansk, the Baltic Sea; (ii) to observe the compositional changes of CDOM and FDOM derived from changes of spectral indices calculated from absorption and EEM spectra; (iii) to describe and distinguish processes that lead to observed differences in CDOM and FDOM concentrations and composition in the SML and SS along the sampled transects.

\section{Measurements}

\subsection{SML sampling}

Sample collection for spectroscopic characterization of the dissolved organic matter contained in the SML and SS, that could be regarded as a proxy for marine surfactants, were conducted during three research cruises of R/V Oceania in April 2015, October 2015 and September 2016. Measurements of physical parameters of seawater and sample col- 

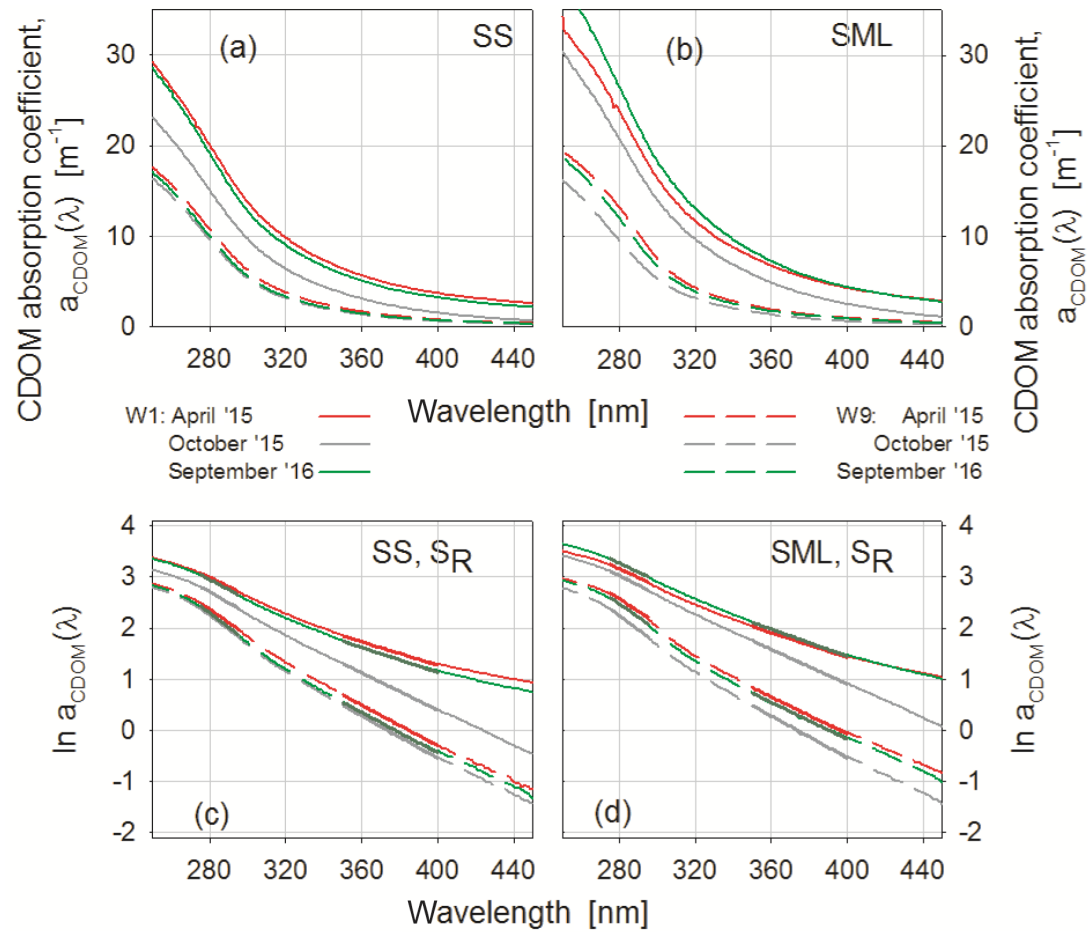

Figure 2. Absorption spectra - collected during three Baltic cruises at 28 April 2015 (red lines), 15-16 October 2015 (grey) and 11 September 2016 (green) - for W1 (solid lines) and W9 (dash lines) stations - presented in linear scale (a, b). Natural log-transformed absorption spectra with best-fit regression lines for two regions $(275-295$ and 350-400 nm) (c, d).

lections were performed at nine stations along the transect "W" - from the mouth of the Vistula River, W1, along the Gulf of Gdansk to the Gdansk Deep in the open sea, W9, (Fig. 1). The Gulf of Gdansk is under direct influence of the main Polish river system, Vistula's, which drains the majority of Poland (Uścinowicz, 2011). Meteorological observations (wind speed and wind direction) were recorded and CTD (the conductivity, temperature and depth - to determine the temperature, salinity and density of seawater) cast with use of the SeaBird SBE 19 probe were performed at every station. Water samples were collected from the SML and SS. The sampling was carried out when the sea state was 0-4 B only, and there were no detectable oil spills. The samples were collected from the board of the vessel (R/V Oceania), which was about $2 \mathrm{~m}$ above the sea surface. The sampling was maintained about $15 \mathrm{~min}$ after anchoring, to avoid the turbulence in the surface layer caused by the screw and ship movements. We used the Garrett Net, mesh 18, to collect the samples from the sea surface microlayer, according to the procedure described by Garrett (1965). The mesh screen is $50 \mathrm{~cm} \times 50 \mathrm{~cm}$, made of metal, and the size of the holes is $1 \mathrm{~mm}$, while the diameter of the wire is $0.4 \mathrm{~mm}$. Thus, the thickness of a collected microlayer is about $0.5 \mathrm{~mm}$. On average, 22 such samplings were required to obtain $1 \mathrm{dm}^{3}$ of microlayer water. First, the screen was immersed. Then, once totally immersed, the screen was left under the water until the microlayer had stabilized. Finally, it was carefully raised to the surface in a horizontal position at a speed of ca. 5$6 \mathrm{~cm} \mathrm{~s}^{-1}$ (Carlson, 1982). Water was poured from the screen into a polyethylene bottle using a special slit in the screen frame. In the same places the SS samples from a depth of $1 \mathrm{~m}$ were taken by a Niskin bottle. Collected, unfiltered water samples were stored in amber glass bottles in the dark at $4{ }^{\circ} \mathrm{C}$ until analysis in the land-based laboratory.

\subsection{Laboratory spectroscopic measurements of CDOM and FDOM optical properties}

Spectrophotometric and spectrofluorometric measurements of collected samples were conducted in the laboratory of the Institute of Oceanology of the Polish Academy of Sciences, Sopot, Poland, within $24 \mathrm{~h}$ after the end of a cruise. Before any spectroscopic measurements the water samples were left to warm up to room temperature.

The main task of our work was to study the luminescent properties of the molecules that form a surface microfilm. However, the sea surface microlayer is a gelatinous film created by polysaccharides, lipids, proteins and chromophoric dissolved organic matter (Sabbaghzadeh et al., 2017; Cunliffe et al., 2013) and consists of dissolved, colloidal and particulate matter. Thus, so as not to dispose of the absorbing and fluorescent matter involved into a gel structure, we do not filtrate the samples. In this paper the results of absorption and fluorescence indices, based on CDOM absorption spec- 
tra and 3-D fluorescence spectra of FDOM, collected during three cruises and carried out on the unfiltered samples are presented. The tests were performed on filtrated and unfiltered probes, sampled during one cruise (not published). Changes in the absorption spectra resulting from the unfiltering of the samples occur mainly in the short UV and far-VIS range. However, these differences do not cause significant changes in the absorption indices, because they are calculated on the basis of the shapes of the spectra (in other words: are based on the relative differences between the values of $a_{\mathrm{CDOM}}(\lambda)$ in the range between the limits of the measuring range. Moreover, in the studied fluorescence spectra, due to lack of filtration, we obtain strong elastic and nonelastic scatter bands, which, however, are removed in the first step of the analysis. The filtration procedure affects the fluorescence spectral band (Fig. 2) for a component $T$ (protein-like) only, which is much more effectively retained on the filter; however, the differences are the same for the SML and SS. Knowing the limitations of the applied procedures, we decide to conduct research on unfiltered water (Ćosović and Vojvodić, 1998; Drozdowska et al., 2015).

CDOM absorption measurements were carried out with the use of Perkin Elmer Lambda 650 spectrophotometers in the spectral range $240-700 \mathrm{~nm}$. All spectroscopic measurements were carried out with the use of $10 \mathrm{~cm}$ quartz cells, and ultrapure Milli-Q water was used as the reference for all measurements. Raw recorded absorbance $A(\lambda)$ spectra were processed and the CDOM absorption coefficients $a_{\mathrm{CDOM}}(\lambda)$ $\left(\mathrm{m}^{-1}\right)$ were calculated according to Eq. (1), as follows:

$a_{\mathrm{CDOM}}(\lambda)=2.303 \times A(\lambda) / l$,

where $A(\lambda)$ is the corrected spectrophotometer absorbance reading at wavelength $\lambda$ and $l$ is the optical path length in meters.

A nonlinear least-squares fitting method using a trustregion algorithm implemented in MATLAB R2011b was applied (Stedmon et al., 2000; Kowalczuk et al., 2006) to calculate CDOM absorption spectrum slope coefficient, $S$, in the spectral range $300-600 \mathrm{~nm}$ using the following equation:

$a_{\mathrm{CDOM}}(\lambda)=a_{\mathrm{CDOM}}\left(\lambda_{0}\right) e^{-S\left(\lambda_{0}-\lambda\right)}+K$,

where $\lambda_{0}$ is $350 \mathrm{~nm}$, and $K$ is a background constant that allows for any baseline shift caused by residual scattering by fine-size particle fractions, micro-air bubbles or colloidal material present in the sample; refractive index differences between sample and the reference; or attenuation not due to CDOM. The parameters $a_{\mathrm{CDOM}}(350), S$ and $K$ were estimated simultaneously via nonlinear regression using Eq. (2) in the spectral range $300-600 \mathrm{~nm}$.

The organic matter fluorescence excitation emission matrix spectra of all collected samples were made using Varian Cary Eclipse scanning spectrofluorometer in a $1 \mathrm{~cm}$ path length quartz cuvette using a $4 \mathrm{~mL}$ sample volume. Series of emission scans (280-600 $\mathrm{nm}$ at $2 \mathrm{~nm}$ resolution) were taken over an excitation wavelength range from 250 to $500 \mathrm{~nm}$ at $5 \mathrm{~nm}$ increments. The instrument was configured to collect the signal using maximum lamp energy and $5 \mathrm{~nm}$ band pass on both the excitation and emission monochromators. Prior to the measurements of each batch of samples the fluorescence EEM spectrum of Milli-Q water blank sample was measured using the same instrumental set-up. The intensity of the Milli-Q water Raman emission band was calculated by integrating the area under the emission spectrum in the spectral range: $374-424 \mathrm{~nm}$, exited at $350 \mathrm{~nm}$ (in the literature: $355 \mathrm{~nm}$ ) (Murphy et al., 2010). The blank Milli-Q fluorescence signal was subtracted from all EEM samples. All blank corrected spectra were normalized to Milli-Q water Raman emission (scaled to Raman units, R.U.) by dividing the resulting spectra by calculated Raman emission intensity value.

\subsection{Optical indices of CDOM and FDOM used for calculations}

\subsubsection{Absorption indices}

Based on measured absorption spectra, several spectral absorption indices have been calculated. The ratios of CDOM absorption coefficients at $250-365 \mathrm{~nm}$, $a_{\mathrm{CDOM}}(250) / a_{\mathrm{CDOM}}(365)$ (called $E_{2}: E_{3}$ ), and at 450 to $650 \mathrm{~nm}, a_{\mathrm{CDOM}}(450) / a_{\mathrm{CDOM}}(650)$ (called $E_{4}: E_{5}$ ), are used to track changes in the relative size and the aromaticity of CDOM molecules (De Haan and De Boer, 1987; Peuravuori and Pihlaja, 1997; Chin et al., 1994). When molecular size and aromaticity increase, the values of the ratios $E_{2}: E_{3}$ and $E_{4}: E_{5}$ decrease. This is caused by the stronger absorption at the longer wavelengths occurring due to the presence of larger and higher molecular weighted CDOM molecules (Helms et al., 2008; Summers et al., 1987). In optically clear natural waters the absorption at $664 \mathrm{~nm}$ is often small or immeasurable, and then the absorption at $254 \mathrm{~nm}$ (or $280 \mathrm{~nm}$ ) is used in lieu of the $E_{4}: E_{5}$ ratio as an indicator of humification or aromaticity (Summers et al., 1987). The spectral slope coefficient, $S$, of the absorption spectra, calculated in various spectral ranges (Carder et al., 1989; Blough and Green, 1995), may be considered as a proxy for CDOM composition, including the ratio of fulvic to humic acids and molecular weight (Stedmon and Markager, 2003; Bracchini at al., 2006). The use of $S$ in the narrow spectral range allows subtle differences in the shape of the spectrum to be revealed, and this in turn gives insight into the origin of organic matter (Sarpal et al., 1995). The use of narrow wavelength intervals is advantageous as they minimize variations in $S$ caused by dilution (Brown, 1977). The ratio of the spectral slope coefficients $\left(S_{275-295}\right.$ and $\left.S_{350-400}\right), S_{\mathrm{R}}$, is correlated with DOM molecular weight (MW) and to photochemically induced shifts in MW (Helms et al., 2008) The spectral slope ratio, $S_{\mathrm{R}}$, was calculated as the spectral slope coefficient ratio estimated by linear fitting of log-transformed absorption 
spectra in the spectral ranges $275-295 \mathrm{~nm},\left(S_{275-295}\right)$ and $350-400,\left(S_{350-400}\right)$. Helms et al. (2008) have reported that the photochemical degradation of terrestrial DOM lead to increases in the absolute value of the spectral slope ratio.

\subsubsection{Fluorescence indices}

Analysis of EEM fluorescence spectra of marine waters is based on interpretation of distinct fluorescence intensity peaks proposed by Coble (1996) (Loiselle et al., 2009) for different types of fluorophores found in natural waters, where peak $A$ (ex./em. - excitation and emission $-250 / 437 \mathrm{~nm}$ ) is attributed to terrestrial humic substances; peak $C$ (ex./em. $310 / 429 \mathrm{~nm}$ ) represents terrestrial fulvic substances; peak $M$ (ex./em. 300/387 nm) characterizes marine fulvic substances; and peak $T$ (ex./em. 270/349 nm) represents proteinaceous substances. Fluorescence intensities of the main FDOM components: $A, C, M$ and $T$ (in R.U.) are used as a proxy of FDOM concentration. A percentile contribution of the main FDOM fluorophores, calculated as the ratio of the respective peak intensity $(A, C, M$ or $T)$ to the sum $(A+C+$ $M+T$ ) of all peak intensities, gives information about the relative changes of a fluorophore composition in a sample (Kowalczuk et al., 2005; Drozdowska and Józefowicz, 2015). The fluorescence intensities ratio $(M+T) /(A+C)$ allows the assessment of the relative contribution of dissolved organic matter recently produced in situ, $(M+T)$, to humic substance characterized by highly complex high molecular weighted (HMW) structures $(A+C)$ (Parlanti et al., 2000; Drozdowska et al., 2015). Values of the $(M+T) /(A+C)$ ratio $>1$ indicate the predominant amount of autochthonous DOM molecules, while values of $<0.6$ indicate the allochthonous ones. The HIX index is calculated as a ratio of fluorescence intensity at a blue-part electromagnetic radiation spectrum $(435-480 \mathrm{~nm})$ to a fluorescence intensity at the UV-A part (330-346 nm), excited at $255 \mathrm{~nm}$ (Zsolnay et al., 1999). The HIX index reflects the structural changes that occurred during the humification process, causing the increase in both aromaticity (the ratio $\mathrm{C} / \mathrm{H}$ ) and molecular weight of DOM molecules. Calculated spectral indices allowed the assessment of DOM structural and compositional changes, as well as quantification of the allochthonous (terrestrial, aromatic and highly weighted molecules) vs. autochthonous (marine humic-like and protein-like and low molecular weighted molecules) DOM fractions in the sampled transect.

\section{Results}

The SML and SS sampling during two research cruises, in April 2015 and September 2016, was conducted in calm sea conditions - the wind speed amounted to zero. In October 2015, a fresh northwestern wind was recorded (3-4 B). This cruise started after a week-long storm of northerly winds that caused an increase in sea level in the southern part of the Gulf of Gdansk and periodically stopped the Vistula River. As the consequence, measured salinity along entire transect $W$ was $>7$, and values of CDOM absorption and FDOM intensities were low, even at the vicinity of the Vistula River mouth.

\subsection{Absorption analysis}

In the Baltic Sea, CDOM absorption decreases with increased salinity (Kowalczuk, 1999; Kowalczuk et al., 2006; Drozdowska and Kowalczuk, 1999), therefore - as expected - CDOM absorption spectra measured at the nearest-shore station W1, are higher in comparison to those measured in outermost station, W9, in the Gdansk Deep, as shown in Fig. 2.

The values of the absorption coefficient, $a_{\mathrm{CDOM}}(\lambda)$, are the highest in the station, W1, located in the vicinity of a river outlet, and the lowest in W9, in the open sea. Moreover, the intensity of light absorption is higher in the SML than in the SS because of the enrichment effect of the surface layer (Williams et al., 1986; Cunliffe at al., 2009), while with the increase in a distance from the river outlet, the intensity of light absorption is decreasing significantly and the differences between the SML and SS decrease (see the calculations published in the open discussion). Furthermore, the slope ratio $S_{\mathrm{R}}$, as a ratio of spectral slope coefficients in two spectral ranges of the absorption spectra, S275-295 and S350400 , was calculated. The sections of the absorption curves, marked in the appropriate narrow spectral ranges, and, corresponding to them, the values of $S_{\mathrm{R}}$ are presented in Fig. 2c and $\mathrm{d}$ and Table 1 , respectively.

The values of $S_{\mathrm{R}}$ obtained during three cruises at W1 station (near the Vistula River outlet) were 1.58, 1.16 and 1.61 for SS and 1.43, 1.10 and 1.35 for the SML, while at W9 (open sea) they were 1.30, 1.33 and 1.40 for SS and 1.34, 1.35 and 1.45 for the SML. Hereof, the slope ratio, $S_{\mathrm{R}}$, was higher in the SML than in the SS in the open sea (W9), while it was opposite in a region around the Vistula river mouth (W1). However, in W9 (the open sea) the differences were $3.1,1.5$ and $3.5 \%$, while in $\mathrm{W} 1$ they were $10.5,5.4$ and $11.9 \%$. The higher values of $S_{\mathrm{R}}$ in the SML in the open sea waters indicate the smaller size of CDOM that may exist due to a photodegradation process (Helms et al., 2008), while the lower values of $S_{\mathrm{R}}$ in the SML in the vicinity of the river outlet may indicate the formation of the surface structures from the hydrophobic molecules coming with freshwater.

Then, other absorption indices that describe the changes of molecular size and weight (the ratio $E_{2}: E_{3}$ ) and the chemical composition of organic matter (a spectral slope coefficient, $S$ ) were calculated. The results of $E_{2}: E_{3}$ and $S$ and $S_{\mathrm{R}}$ in relation to salinity are presented in Fig. 3. The satisfying correlation between salinity and (i) the spectral slope coefficient, $S$ ( $r^{2}=0.84$ for SS and $r^{2}=0.67$ for SML), (ii) the slope ratio $S_{\mathrm{R}}\left(r^{2}=0.58\right.$ for SS and SML) and (iii) relative changes in the molecular weight MW $\left(r^{2}=0.94\right.$ for SS and 


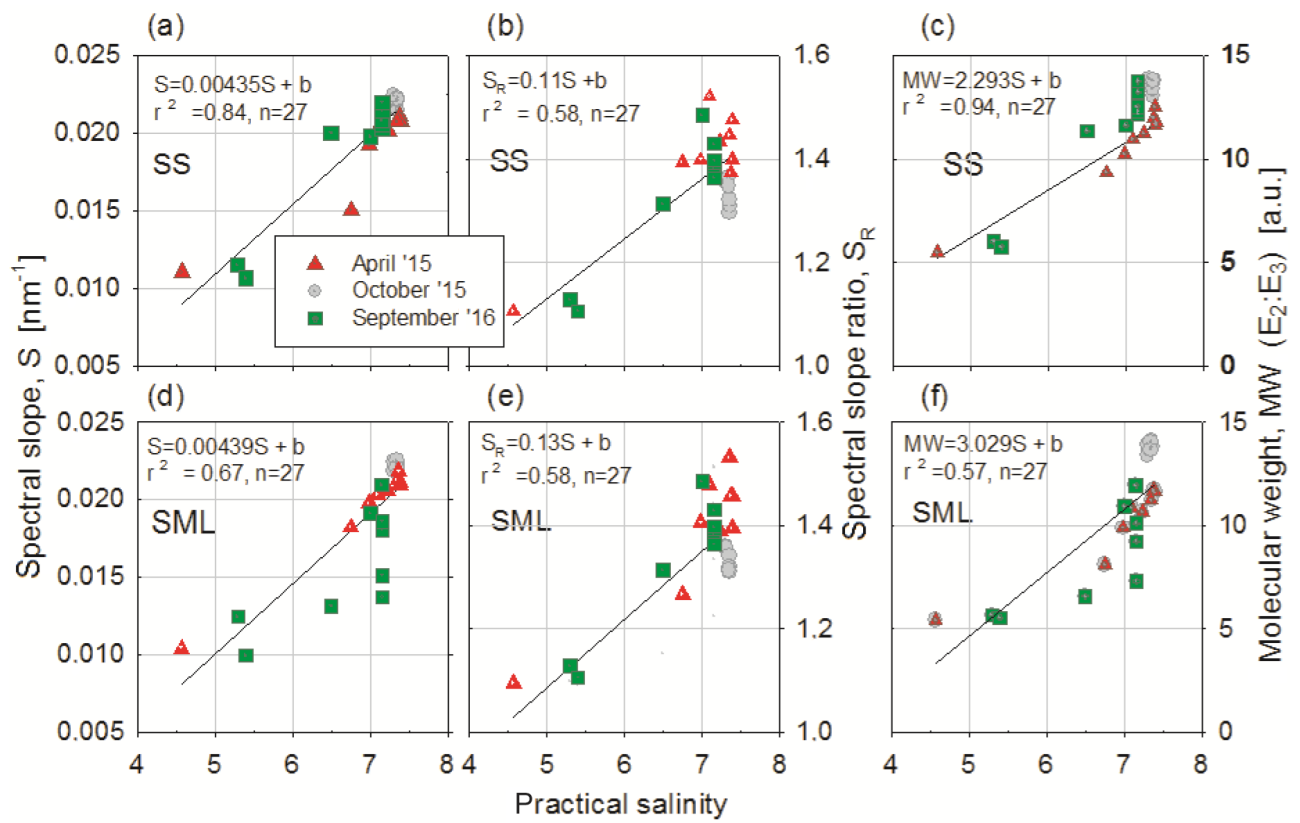

Figure 3. The relationship between salinity and (a) the spectral slope coefficient, $S$, measured in the $300-600 \mathrm{~nm}$; (b) the slope ratio $S_{\mathrm{R}}=$ $S_{275-295} / S_{350-400}$; and (c) the relative changes in the molecular weight, MW ( $\left.E_{2}: E_{3}\right)$, for the SS. The panels (d), (e) and (f) show the same for the SML, respectively.

Table 1. Results of a slope ratio, $S_{\mathrm{R}}$, for SML and SS, at W1 and W9 stations.

\begin{tabular}{rrrr|rrr}
\hline \multicolumn{5}{c}{ A slope ratio $-S_{\mathrm{R}}\left(=S_{275-295} / S_{350-400}\right)$} \\
\hline & 28 April & $15-16$ October & 11 September & 28 April & 15-16 October & 11 September \\
& 2015 & 2015 & 2016 & 2015 & 2015 & 2016 \\
\hline W1 & 1.58 & 1.16 & 1.61 & 1.43 & 1.10 & 1.35 \\
W9 & 1.30 & 1.33 & 1.40 & 1.34 & 1.35 & 1.45 \\
\hline
\end{tabular}

$r^{2}=0.57$ for SML) were obtained. The calculations were performed by regression statistics, with the confidence interval $95 \%$. Moreover, the linear regression coefficients for the relations between salinity and $S, S_{\mathrm{R}}$ and MW are respectively $0.00439,0.13$ and 3.029 for the SML and 0.00435, 0.11 and 2.293 for the SS. As one can see, the linear regression coefficients achieved higher values for the SML than the SS, so the processes go faster in the SML than in the SS.

Furthermore, the values of $S, S_{\mathrm{R}}$ and MW are 2, 0.5 and 3 times higher, respectively, in the vicinity of the river outlet than in the open sea.

\subsection{Fluorescence analysis}

The studies on the fluorescence properties of seawater, focused on the surface layer, were developed in the Baltic Sea for years (Ferrari and Dowell, 1998; Drozdowska and Kowalczuk, 2009; Drozdowska, 2007a, b) and allowed for complex analysis of the natural components of the Baltic Sea water
(Kowalczuk et al., 2005; Stedmon et al., 2003). Based on the analysis of 54 EEM spectra of seawater (27 samples for the SML and 27 for the SS) the intensities of four emission bands (in R.U.), belonging to the main components ( $A, C, M$ and $T$ ) of the marine CDOM, were calculated. Figure 4 presents the 3-D EEM spectra, typical for the open sea water (the most salty), W9, and estuarine waters (the most fresh), W1, for the samples collected from the SML and SS.

The relationships between the fluorescence intensities of the main fluorescence bands (proxies of FDOM components concentration) and salinity as well as the relative contribution of the fluorescent components and salinity are demonstrated in Figs. 5 and 6. The changes of the FDOM peak intensities and their relative contributions (composition of FDOM components) in EEM were quantified by calculating the median and its percentile distribution of both the fluorescence intensities and the relative contributions of FDOM components, for the SML and SS, in two water masses. Table 2 contains the median values of (i) fluorescence intensities (R.U.) and 


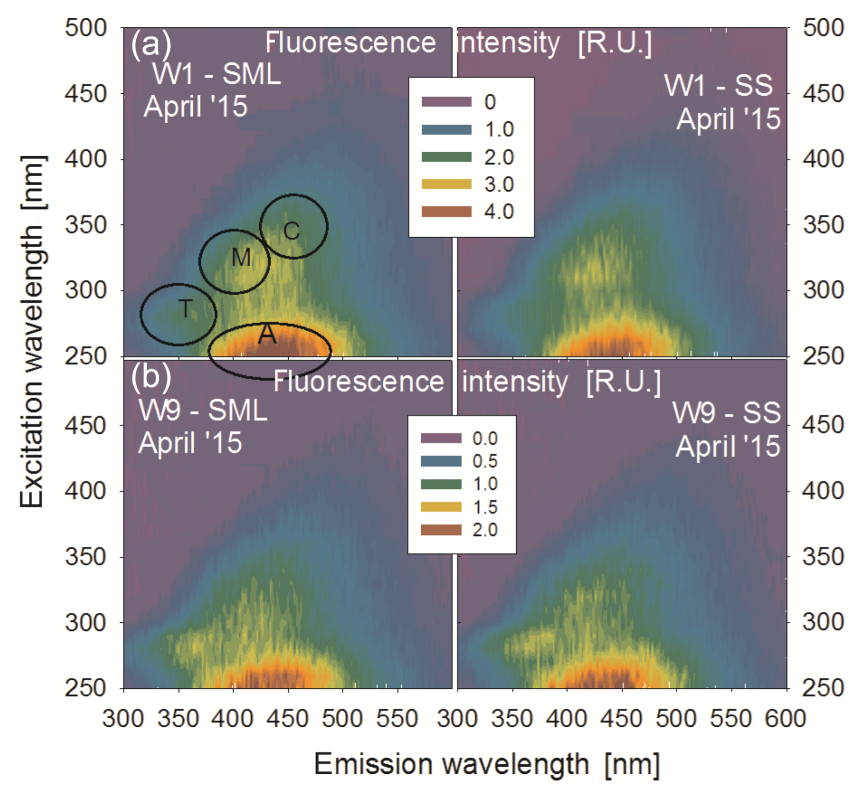

Figure 4. Examples of 3-D fluorescence spectra (EEM) of the samples collected at stations W1, near the Vistula River outlet (a), and W9, Gdansk Deep (b), from the SML and SS - at the left and rigth side, respectively.

(ii) percentage contribution (\%) of respective peaks in the SML and SS in two distinct water masses: one characterized by salinity $<7$, which is influenced by direct freshwater discharge from the Vistula River, and the other characterized by salinity $>7$, which is typical for the open Baltic Sea waters. The ANOVA test was applied to the mentioned median values for two cases: when the differentiation factor was (i) the salinity regime and (ii) the sampling layer. The salinity was a good factor to differentiate the variances of the median values, while the sampling layer was not. However, in spite of the $p$ values indicating no statistical significance, one can see in the graphs and Table 2 that the values for the SML are always higher than for the SS. Hence, the distinction between the results for the SML and SS exists. Furthermore, the differentiation factor is the level of sampling. The fluorescence intensities of the main FDOM components, in reference to salinity, demonstrate the constant linear relationships both in the SS and SML (Fig. 5, upper and lower graphs, respectively). The linear regression coefficients were calculated by the regression test, with the confidence interval $95 \%$. The linear coefficients in the SML and SS, for every FDOM component, are -1.43 and -1.02 for a component $A,-0.84$ and -0.65 for a component $C,-0.56$ and -0.43 for a component $M$, and -0.32 and -0.3 a component $T$, respectively. Hence the regression coefficients are higher in the SML than in the SS.

The percentile statistical distribution of fluorescence peak intensities in the SML and SS layer in two water masses, characterized by salinity threshold less than 7 and higher than 7, have been presented in Fig. 6a and b, respectively. The box-whisker plots in Fig. 6 present median values (solid line), 25th and 75th percentiles (the boundaries of the box: closest to and farthest from zero, respectively), and 5th and 95th percentiles (whiskers below and above the box, respectively) of the respective fluorescence intensity. There has been a clear spatial pattern (for the coastal zone and open sea) shown on both figures: the higher median values of $A, C, M$ and $T$ were observed in the SML than in the SS. For salinity $<7$ the median of fluorescence intensities of the main FDOM components in the SML were 2.69, 2.27, 1.74 and 0.98 R.U., while in the SS they were 2.31, 1.27, 1.12 and 0.86 R.U. In open waters (salinity $>7$ ) the median of fluorescence intensities of the FDOM components in the SML were 1.56, $0.84,0.85$ and 0.69 R.U., while in the SS they were 1.5, 0.77, 0.76 and 0.63 R.U. The median values of respective peaks intensities are higher in the SML than in the SS both in coastal zone (salinity $<7$ ) and in the open sea (salinity $>7$ ). Additionally, the boundaries of the boxes show much greater dispersion of the results in the SML than in the SS and greater variation in the coastal zone (salinity $<7$ ) than in the open sea (salinity $>7$ ).

The Fig. 7 shows the percentage contribution of the individual FDOM peaks calculated as the ratio of its fluorescence intensity to the sum of the all fluorescence peak intensities (e.g., $A /(A+C+M+T)$ for SS and SML samples (the left and the right graph, respectively). The box-whisker plots in Fig. 7 present median values (solid line), 25th and 75th percentile (the boundaries of the box: closest to and farthest from zero, respectively), and 5th and 95th percentiles (whiskers below and above the box, respectively) of the respective percentage contribution (a relative composition of fluorescing components of $\mathrm{CDOM}$ ).

For salinity $<7$, the medians of the percentage contribution of $A, C, M$ and $T$ components of marine FDOM in the SML were 40.72, 24.32, 20.01 and $14.06 \%$ while in the SS they were $41.52,22.87,19.92$ and $14.40 \%$, respectively. In open waters (salinity $>7$ ) the median values of FDOM components composition in the SML were $39.08,22.43,20.53$ and $16.89 \%$ while in the SS they were $40.75,22.17,20.90$ and $16.27 \%$. So, the contribution of two terrestrial components $(A$ and $C)$ decreased with increasing salinity $(\sim 1.64$ and $\sim 1.89 \%$ in the SML and $\sim 0.78$ and $\sim 0.71 \%$ in the SS, respectively), while the contribution of components produced in situ in the sea ( $M$ and $T$ ) increased with salinity $(\sim 0.52$ and $\sim 2.83 \%$ in the SML and $\sim 0.98$ and $\sim 1.87 \%$ in the SS, respectively), Fig. 7. Considering the aforementioned changes for an individual component in relation to its percentage contribution, the values of their relative changes can be calculated. Hereby, the highest relative changes of the FDOM component composition, along the transect from the Vistula River outlet to Gdansk Deep, were recorded for component $\mathrm{T}$, in both the SML and SS (about 18.5 and $~ 12.3 \%$, respectively), while the relative changes of $\mathrm{A}, \mathrm{C}$ and $\mathrm{M}$ com- 

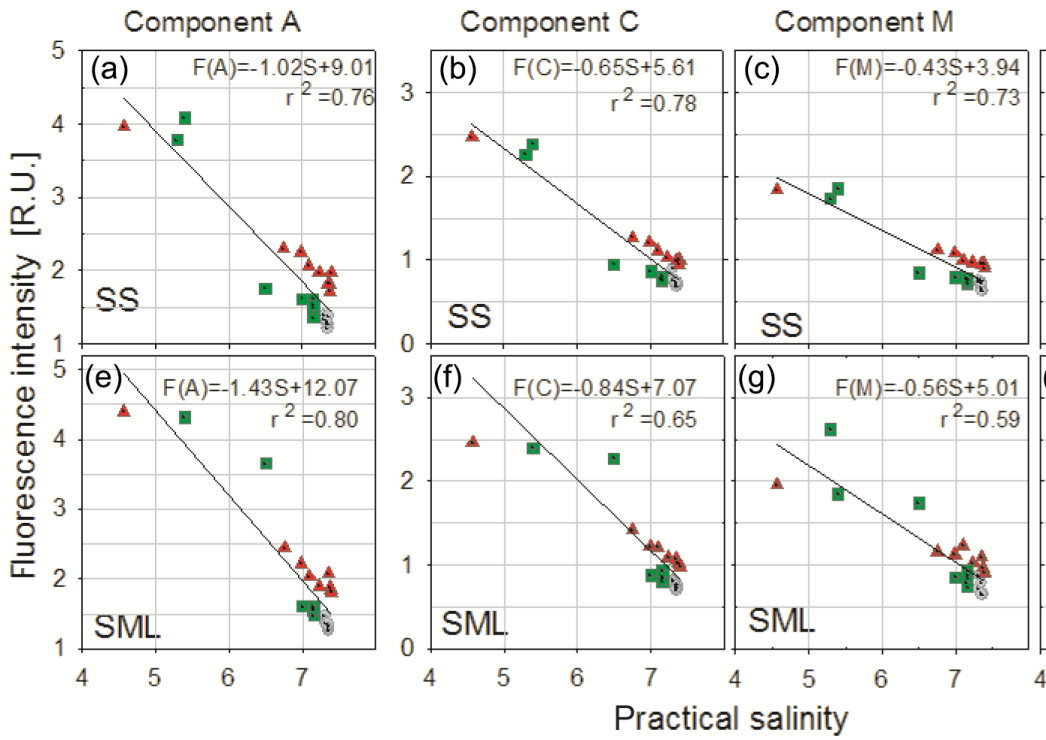

Component $\mathrm{T}$

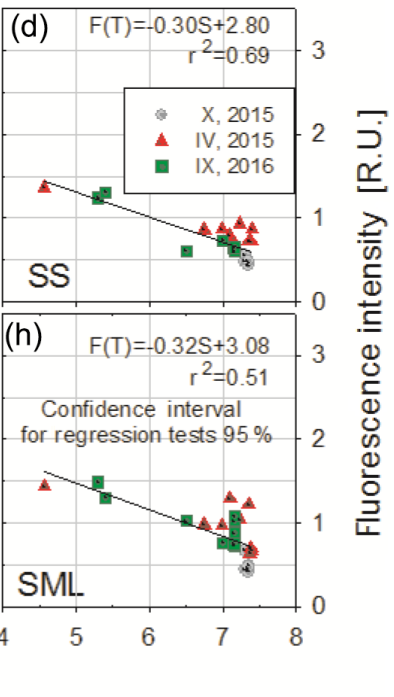

Figure 5. Dependence of the fluorescence intensity of the main FDOM components, (a) $A$, (b) $C$, (c) $M$ and (d) $T$, as a linear relation to salinity for the samples from the subsurface water (SS; a-d) and the sea surface microlayer (SML; $\mathbf{e}-\mathbf{h})$.

Table 2. Medians of the fluorescence intensity and percentage contribution of FDOM components for coastal zone (typical for salinity $<7$ ) and open sea waters (typical for salinity $>7$ ).

\begin{tabular}{|c|c|c|c|c|c|c|c|c|c|c|}
\hline & & & \multicolumn{4}{|c|}{ Salinity $<7$} & \multicolumn{4}{|c|}{ Salinity $>7$} \\
\hline \multicolumn{3}{|c|}{ FDOM components } & $A$ & $C$ & $M$ & $T$ & $A$ & $C$ & $M$ & $T$ \\
\hline \multicolumn{3}{|c|}{ exc./em. (nm/nm) } & $250 / 437$ & $310 / 429$ & $300 / 387$ & $270 / 349$ & & & & \\
\hline \multirow{2}{*}{$\begin{array}{l}\text { Fluorescence } \\
\text { intensity, } \\
\text { (R.U.) }\end{array}$} & \multirow{2}{*}{ 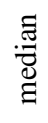 } & SML & 2.69 & 2.27 & 1.74 & 0.98 & 1.56 & 0.84 & 0.85 & 0.69 \\
\hline & & SS & 2.31 & 1.27 & 1.12 & 0.86 & 1.50 & 0.77 & 0.76 & 0.63 \\
\hline \multirow{2}{*}{$\begin{array}{l}\text { Percentile } \\
\text { contribution, } \\
(\%)\end{array}$} & \multirow{2}{*}{ 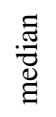 } & SML & 40.72 & 24.32 & 20.01 & 14.06 & 39.08 & 22.43 & 20.53 & 16.89 \\
\hline & & SS & 41.52 & 22.87 & 19.92 & 14.40 & 40.75 & 22.17 & 20.90 & 16.27 \\
\hline
\end{tabular}

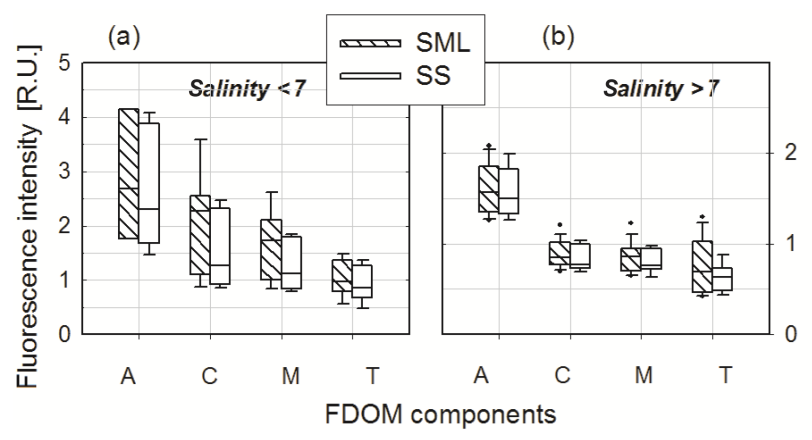

Figure 6. Dependence of the fluorescence intensity of the main FDOM components in the SML and SS as the box plots for (a) coastal water (salinity $<7$ ) and (b) open sea (salinity $>7$ ).

ponents were 4.1, 8.1 and $2.6 \%$ in the SML and 1.9, 3.1 and $4.7 \%$ in the SS, respectively. (a)

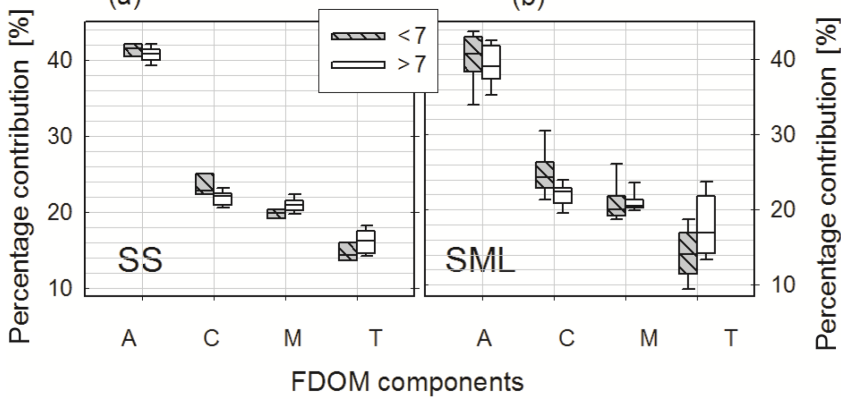

Figure 7. Dependence of the percentage contribution of the main FDOM components as the box plots for (a) the subsurface water, SS and (b) the sea surface microlayer, SML; for the coastal waters (salinity $<7$ ) and open sea (salinity $>7$ ). 
(a)

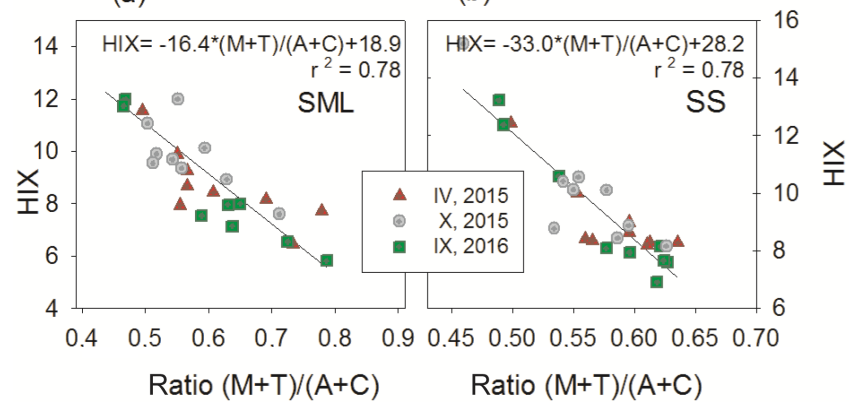

Figure 8. The relationship between the ratio $(M+T) /(A+C)$ and the HIX index for (a) SML and (b) SS water.

The values of peak intensities $(A, C, M$ and $T)$ allowed the calculation of (i) the ratio $(M+T) /(A+C))$ and (ii) the HIX index in the SML and SS water, presented in Fig. 8.

The low values of the ratio $(M+T) /(A+C)(<\sim 0.6)$ were recorded in almost all samples from a subsurface layer, SS, but only in the SML samples from the Gulf of Gdansk. The ratios varied along the transect $\mathrm{W}$ in the range 0.47 to 0.79 for SML and 0.49 to 0.63 for SS, from W1 to W9 respectively. Thus, the ratio describes the process that occurs more effectively in the SML. The results of the HIX index achieved higher values in the SS than in the SML. Additionally, the HIX index changed in the SML in a range from 5.8 to 11.9, while in the SS it ranged from 6.9 to 13.2. The elevated values of HIX in the SS indicate a presence of molecules of higher molecular weight that are more condensed, with higher aromaticity, in the SS than in the SML (Fig. 8).

\subsection{The absorption and fluorescence dependences}

The absorption and fluorescence results allow comparison of the spectral slope ratio, $S_{\mathrm{R}}$, with the HIX index and the ratio $E_{2}: E_{3}$ to find the dependences of the molecular size and weight in the SML and SS on the condensation degree of organic molecules and on the changes in chemical composition of organic matter; see Fig. 9 (Helms at al., 2008; Chen et al, 2011; Vähätalo and Wentzel, 2004; Zhang et al., 2013). High values of the HIX index of ca. 11-16, coincide with low values of $S_{\mathrm{R}}$, ca. 1-1.2 (Zsolnay et al., 1999; Chari et al., 2012). While $S_{275-295}<S_{350-400}$ indicates the occurrence and predominance of highly condensed matter, as a dominance of and/or terrestrial DOM, with HMW molecules absorbing in a long-wavelength range (Helms et al., 2008; Chen et al., 2011), the lower HIX and higher $S_{\mathrm{R}}$ values $\left(S_{275-295}>S_{350-400}\right)$ indicate the predominance of marinederived low molecular weighted LMW molecules absorbing in a short-wavelength range (Chen et al., 2011). The relation between the HIX index and $S_{\mathrm{R}}$ shows a simple linear relation in subsurface waters. However, in the sea surface microlayer, the changes in organic matter composition are nonlinearly related to the changes taking place in DOM

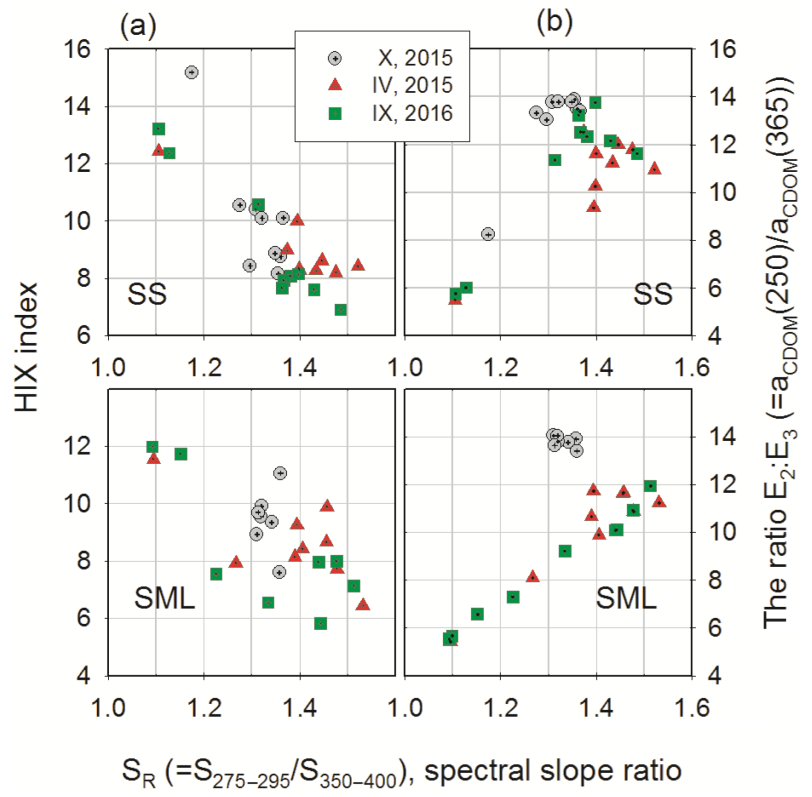

Figure 9. The relationship between the spectral slope ratio, $S_{\mathrm{R}}$, and (a) the HIX index and (b) the ratio $E_{2}: E_{3}$ - for SS and SML, in the upper and lower graphs, respectively.

molecules undergoing the degradation processes reflected by HIX values. The HIX index is sensitive to the humification and condensation processes, focused on large, high-weighted organic molecules, that mainly reflect the changes in a longwavelength range (above $330 \mathrm{~nm}$ ). However, the photochemical degradation processes, resulting in a decrease in the mass of molecules and an increase in the concentration of low molecular weighted molecules, are much more pronounced in the lower-wavelength range and are held primarily in the surface microlayer (Chin et al., 1994; Fuentes et al., 2006). For the same reason mentioned above, the relation between the ratio $E_{2}: E_{3}$ and $S_{\mathrm{R}}$ is better correlated in SML than SS water (Helms et al., 2008). Moreover, the relation between the $E_{2}: E_{3}$ and $S_{\mathrm{R}}$ (both inversely proportional to molecular size and weight) shows more discrete differences in molecular structure of the organic molecules studied in different seasons and allows the different nature of the water tested in October 2015 to be noted (Helms et al., 2008). The values of the ratio $E_{2}: E_{3}$ (inversely proportional to molecular size and weight of molecules), calculated for the data collected in October 2015, point to the extremely small size as well as almost the same size and weight of organic molecules investigated in the entire study region in both the SML and SS (De Haan and De Boer, 1987; Helms et al., 2008). That confirms very well-mixed water in the surface layer in the study area during October 2015, suggested previously by the meteorological observations. 


\section{Discussion}

The values of the absorption coefficient, $a_{\mathrm{CDOM}}(\lambda)$, show that the intensity of light absorption (a proxy of the amount of organic matter) is decreasing significantly with an increase in distance from the river outlet, in both the SML and SS (Tilstone et al., 2010; Stedmon et al., 2000; Twardowski and Donaghay, 2001; Kowalczuk et al, 1999). It shows that the main source of CDOM in the study area is the Vistula River (Ferrari and Dowell, 1998; Kowalczuk et al., 2005). Additionally, the higher values of the absorption were detected in the SML than in the SS, what is called the enrichment effect. It was studied for diverse range of microlayer components in different aquatic systems (Carlson, 1982; Williams et al., 1986; Wurl et al., 2009). Moreover, the differences between the values of the absorption coefficients calculated for the SML and SS decrease with the increase in salinity, which was reported as the effect of conversion of particulate organic matter to DOM, enhanced in the SML, by extracellular enzyme activity and export of DOM formed in the SML to subsurface layers (Kuznetsowa and Lee; 2001; Wurl et al., $2009)$ The analysis of several absorption indices $\left(S, S_{\mathrm{R}}\right.$ and $E_{2}: E_{3}$ ) reveal the changes in composition and a decrease in molecular weight of organic matter with an increase in salinity and distance from the mouth of the river (Helms at al., 2008). Molecules brought into the sea with the river waters, with increasing salinity (and time and the distance from the mouth of the river), undergo such processes as the dilution of the fresh waters in sea waters and the degradation of the organic particles, induced by solar radiation (photobleaching) and by bacterial activity (biodegradation) (Moran et al., 2000; Helms et al., 2008). The increases in $S, S_{\mathrm{R}}$ and $E_{2}: E_{3}$ (a proxy of a decrease in molecular weight) with salinity suggest a transfer of colored material from the HMW fraction to the LMW fraction (Helms et al., 2008). Moreover, the linear regression coefficients for the relations between salinity and: $S, S_{\mathrm{R}}$ and $E_{2}: E_{3}$ achieved higher values for the SML than for the SS (Zhang et al., 2013). The values of the linear regression coefficients can illustrate a rate of the breakdown of large molecules to smaller ones (HMW to LMW) (Zhang et al., 2013; Timko et al., 2015; Helms et al., 2008). They achieve the higher values in the SML than in the SS, thus showing that the dependence is stronger in the SML than in the SS. Furthermore, the values of $S, S_{\mathrm{R}}$ and $E_{2}: E_{3}$, are smaller in the vicinity of the river outlet by about $2,0.5$ and 3 times, respectively, than in the open sea, depicting a presence of higher molecular weighted molecules in the estuarine waters, in both the SML and SS. Hence, the higher values of $S_{\mathrm{R}}$ indicate an increase in absorption in a shortwavelength range (via an increase in concentration of lowweighted molecules) and a decrease in absorption in a longer wavelength range (a decrease in the concentration of big and more condensed and high-weighted molecules) (Helms et al., 2008; Peravuori and Pihlaja, 1997; Osburn et al., 2011). However, in the vicinity of the river mouth (W1), the studied absorption indices reached lower values in the SML than in the SS. It suggests that the molecules with large molecular mass are predominant in a surface microlayer. Such results may be caused by the presence of the surface slicks, visible to the naked eye, made of large surface molecular structures. Riverine water brings into the sea a huge amount of the terrestrial amphiphilic (the molecules with hydrophobic and hydrophilic heads) organic molecules that form the surface slicks, and despite the large weight of the surface molecular structures their hydrophobic properties make them float on the sea surface (Cunliffe et al., 2011).

The spectrofluorometric studies complete and confirm the absorption studies, wherein the concentration of components $A, C, M$ and $T$ were higher in the SML than in the SS in both the coastal zone and open sea; the contribution of $A$ and $C$ components in FDOM composition decreased, while $M$ and $T$ increased, with an increase in salinity (Yamashita et al., 2008; McKnight et al., 2001). Moreover, the values of the fluorescence intensity of FDOM components change linearly with salinity and the linear regression coefficients show higher values in the SML than in the SS (Vodacek et al., 1997; Williams et al., 2010). This may confirm a higher rate of the degradation processes occurring in the SML. The relative changes of the percentage contribution of FDOM components, with an increase in salinity, depict that a component whose quantity varies the most is a fluorophore $T$. It may indicate production of protein-like fluorophores caused by photobleaching and biological activity (Blough and Del Vecchio, 2002;). Additionally the results of the FDOM measurements indicate that FDOM concentration is about 2-3 times higher in the coastal zone (salinity $<7$ ) than in the open sea $(>7)$. The results of FDOM concentration indicate the dominance of terrestrial molecules (allochthonous) in estuarine waters due to high concentration of molecules brought by a river ( $A$ and $C)$. The ratio $(M+T) /(A+C)$ increased with salinity and reached the highest values in the open sea: 0.79 and 0.63 in the SML and SS, respectively (Parlanti et al, 2000; Wilson and Xenopoulos, 2009; Huguet et al., 2009). The photodegradation effect, induced by solar radiation on the molecules in a sea surface layer, results in degradation of macromolecules into particles with a lower molecular weight (i.e., a decrease in $A$ and $C$ and an increase in the amount of molecules of lower molecular weight produced in the sea $(M$ and $T)$ ), and this process acts more rapidly in the SML; see Fig. 8 (Huguet et al., 2009). The above conclusion is confirmed by the ratio $(M+T) /(A+C)$ and the HIX index, which achieve respectively higher and lower values in the SML than in the SS due to higher fluorescence intensity at a short-wavelength band belonging to marine FDOM components ( $M$ and $T$ ) (Chari et al., 2012; Stedmon and Markanger, 2003; Murphy et al., 2010; Mopper and Schults, 1993). The elevated values of HIX in the SS are the evidence of a more advanced humification process of the organic molecules that make the organic molecules more condensed and increase their aromaticity (Zsolnay et al., 1999). 


\section{Conclusions}

The results of the studies on the absorption and fluorescence properties of the organic matter included in SML and SS waters are complementary. The values of the absorption coefficients as well as the fluorescence intensity give information about the decline in the CDOM and FDOM concentrations with increasing salinity, in both the SS and the SML; however, the values of the absorption and fluorescence indices indicate the enrichment effect in the surface microlayer. Moreover, a decreasing of DOM concentration with salinity occurs faster in the SML than in the SS. Analysis of absorption and fluorescence spectra allow the detection of subtle changes in the percentage composition of CDOM and FDOM components that revealed an increase in $M$ and $T$ (produced in situ, in the sea) and a simultaneous decrease in $A$ and $C$ (terrestrial origin) with increasing salinity. Furthermore, the changes of the dependence of a percentage composition and salinity occur in the SML more rapidly than in the SS. The results suggest a higher rate of degradation processes in a surface microlayer (Drozdowska et al., 2015; Timko et al., 2015).

In addition, the analysis of indices obtained from the values of the intensity of the absorption and fluorescence of the samples enabled tracking sources and processes, which affected investigated molecules, in the SML and SS. The authors confirm that (i) the processes of structural changes in molecules of HMW to LMW, due to effects of photoand biodegradation, occur faster in the SML than in the SS (Helms et al., 2008); (ii) organic molecules contained in a surface microlayer have a smaller molecular mass than the SS, and thus SML and SS are characterized by different percentage distributions of the main FDOM components (Helms et al., 2008; Engel et al., 2017); (iii) the freshwater of the Vistula River is the main driving force of the allochthonous character of organic matter in coastal waters of the Gulf of Gdansk.

In summary, the distributions of light intensity reached over or below the sea surface is modified effectively by the specific absorption and/or emission of a light by surfactants. The degradation processes of the organic molecules contained in the SML and SS proceed at different rates. Hence, the DOM molecules included in the SML can specifically modify the physical processes associated with the sea surface layer. It is necessary to continue a study on the physical properties of surface microlayer at other sites of the Baltic Sea and in less urbanized and more natural and pristine regions, such as the Arctic.

Data availability. The data sets used in this study are stored in the Institute of Oceanology of the Polish Academy of Sciences Oceanographic Data and Information Management System https: //www.iopan.pl/data/lidar and can be accessed upon request to Violetta Drozdowska (drozd@iopan.pl). The zip file (OS_2017.zip) consists of three subfolders linked to the respective scientific cruise (with the absorption and fluorescence spectra) and the Excel file (with the CTD and meteo data).

Author contributions. VD designed the experiment, performed the analysis and wrote the paper. PK provided laboratory instrumentation for spectroscopic analysis, gave scientific guidance and contributed to the paper. IW contributed to the field works on the board of the R/V Oceania and to the laboratory measurements. AP contributed to laboratory measurements. PMak and PMar provided the meteorological data and contributed to the field works at the board of the R/V Oceania. All authors reviewed and commented on the paper.

Competing interests. The authors declare that they have no conflict of interest.

Acknowledgements. The work described in this paper was supported by a grant of ESA (European Space Agency) OCEAN FLUX, no. 502-D14IN010. We also acknowledge the support from the funds of the Leading National Research Centre (KNOW) received by the Centre for Polar Studies for the period 2014-2018.

Edited by: Oliver Zielinski

Reviewed by: three anonymous referees

\section{References}

Andrade-Eiroa, Á., Canle, M., and V. Cerdá, V.: Environmental applications of excitation-emission spectrofluorimetry, An in-depth Review II, Appl. Spectrosc. Rev., 48, 77-141, https://doi.org/10.1080/05704928.2012.692105, 2013.

Blough, N. V. and Del Vecchio, R.: Chromophoric DOM in the coastal environment, in: Biogeochemistry of Marine Dissolved Organic Matter, edited by: Hansell, D. and Carlson, C., Academic Press, New York, 509-546, 2002.

Blough, N. V. and Green, S. A.: Spectroscopic characterization and remote sensing of nonliving organic matter, in: Role of nonliving organic matter in the earth's carbon cycle, edited by: Zepp, R. G. and Sonntag, C., Wiley, New York, 23-45, 1995.

Boehme, J. and Wells, M.: Fluorescence variability of marine and terrestrial colloids: Examining size fractions of chromophoric dissolved organic matter in the Damariscotta River estuary, Mar. Chem., 101, 95-103, https://doi.org/10.1016/j.marchem.2006.02.001, 2006.

Bracchini, L., Cózar, A., Dattilo, A. M., Loiselle, S. A., Tognazzi, A., Azza, N., and Rossi, C.: The role of wetlands in the chromophoric dissolved organic matter release and its relation to aquatic ecosystems optical properties. A case of study: Katonga and Bunjako Bays (Victoria Lake, Uganda), Chemosphere, 63, 1170-1178, https://doi.org/10.1016/j.chemosphere.2005.09.045, 2006.

Brown, M.: Transmission spectroscopy examinations of natural waters, Estuar. Coast. Mar. Sci., 5, 309-317, https://doi.org/10.1016/0302-3524(77)90058-5, 1977. 
Carder, K. L., Steward, R. G., Harvey, G. R., and Ortner, P. B.: Marine humic and fulvic acids: their effects on remote sensing of ocean chlorophyll, Limnol. Oceanogr., 34, 68-81, 1989.

Carlson, D. J.: A field evaluation of plate and screen microlayer sampling techniques, Mar. Chem., 11, 189-208, https://doi.org/10.1016/0304-4203(82)90015-9, 1982.

Carlucci, A. F., Craven, D. B., and Henrichs, S. M.: Surfacefilm microheterotrophs: amino acid metabolism and solar radiation effects on their activities, Mar. Biol., 85, 13-22, https://doi.org/10.1007/BF00396410, 1985.

Chari, N. V. H. K., Sarma, N. S., Pandi, S. R., and Murthy, K. N.: Seasonal and spatial constraints of fluorophores in the midwestern Bay of Bengal by PARAFAC analysis of excitation emission matrix spectra, Estuar. Coast. Shelf. S., 100, 162-171, https://doi.org/10.1016/j.ecss.2012.01.012, 2012.

Chen, H., Zheng, B., Song, J., and Qin, Y.: Correlation between molecular absorption spectral slope ratios and fluorescence humification indices in characterizing CDOM, Aquat. Sci, 73, 103112, https://doi.org/10.1007/s00027-010-0164-5, 2011.

Chin, Y.-P., Aiken, G., and O'Loughlin, E.: Molecular weight, polydispersity, and spectroscopic properties of aquatic humic substances, Environ. Sc. Technol., 28, 1853-1858, https://doi.org/10.1021/es00060a015, 1994.

Coble, P.: Characterization of marine and terrestrial DOM in seawater using excitation-emission matrix spectroscopy, Mar. Chem. 51, 325-346, https://doi.org/10.1016/0304-4203(95)00062-3, 1996.

Coble, P.: Marine optical biogeochemistry: the chemistry of ocean color, Chem. Rev., 107, 402-418, https://doi.org/10.1021/cr050350+, 2007.

Coble, P. G., Lead, J., Baker, A., Reynolds, D. M., and Spencer, R. G. (Eds.): Aquatic Organic Matter Fluorescence, Cambridge University Press 375 pp., https://doi.org/10.1017/CBO9781139045452, 2014.

Ćosović, B. and Vojvodić, V.: Voltammetric Analysis of Surface Active Substances in Natural Seawater, Electroanal, 10, 429-434, https://doi.org/10.1002/(SICI)15214109(199805)10:6<429::AID-ELAN429>3.0.CO;2-7, 1998.

Cunliffe, M., Salter, M., Mann, P. J., Whiteley, A. S., UpstillGoddard, R. C., and Murrell, J. C.: Dissolved organic carbon and bacterial populations in the gelatinous surface microlayer of a Norwegian fjord mesocosm, FEMS Microbiol. Lett., 299, 248254, https://doi.org/10.1111/j.1574-6968.2009.01751.x, 2009.

Cunliffe, M., Upstill-Goddard, R. C., and Murrell, J. C.: Microbiology of aquatic microlayers, FEMS Microbiol. Rev., 35, 233-246, https://doi.org/10.1111/j.1574-6976.2010.00246.x, 2011.

Cunliffe, M. A., Engel, S., Frka, S, Gašparović, B, Guitart, C., Murrell, J. C., Salter, M., Stolle, C., Upstill-Goddard, R., and Wurl, O.: Sea surface microlayers: A unified physicochemical and biological perspective of the air-ocean interface, Prog. Oceanogr., 109, 104-116, https://doi.org/10.1016/j.pocean.2012.08.0, 2013.

De Haan, H. and De Boer, T.: Applicability of light absorbance and fluorescence as measures of concentration and molecular size of dissolved organic carbon in humic Lake Tjeukemeer, Water Res., 21, 731-734, https://doi.org/10.1016/00431354(87)90086-8, 1987.

Drozdowska, V.: The lidar investigation of the upper water layer fluorescence spectra of the Baltic Sea, Eur. Phys. J.-Spec. Top., 144, 141-145, https://doi.org/10.1140/epjst/e2007-00118-7, 2007a.
Drozdowska, V.: Seasonal and spatial variability of surface seawater fluorescence properties in the Baltic and Nordic Seas: results of lidar experiments, Oceanologia, 49, 59-69, 2007b.

Drozdowska, V. and Józefowicz, M.: Spectroscopic studies of marine surfactants in the southern Baltic Sea, Oceanologia, 57, 159167, https://doi.org/10.1016/j.oceano.2014.12.002, 2015.

Drozdowska, V. and Kowalczuk, P.: Response of a lidar-induced fluorescence signal to yellow substance absorption, Oceanologia, 41, 601-608, 1999.

Drozdowska, V., Babichenko, S., and Lisin, A.: Natural water fluorescence characteristics based on the lidar investigations of the water surface layer polluted by an oil film; the Baltic cruise May 2000, Oceanologia, 44, 339-354, 2002.

Drozdowska, V., Freda, W., Baszanowska, E., Rudź, K., Darecki, M., Heldt, J. R., and Toczek, H.: Spectral properties of natural and oil polluted Baltic seawater - results of measurements and modeling, Eur. Phys. J.-Spec. Top., 222, 1-14, https://doi.org/10.1140/epjst/e2013-01992-x, 2013.

Drozdowska, V., Kowalczuk, P., and Józefowicz, M.: Spectrofluorometric characteristics of fluorescent dissolved organic matter in a surface microlayer in the southern Baltic coastal waters, J. Eur. Opt. Soc.-Rapid, 10, 15050, https://doi.org/10.2971/jeos.2015.15050, 2015.

Engel, A., Bange, H. W., Cunliffe, M., Burrowa, S. M., Friedeichs, G., Galgani, L., Herrmann, H., Schartau, N., Soloviev, A., Stolle, C., Upstill-Goddard, R. C., van Pinxteren, M., and Zäncker, B.: The ocean's vital skin: toward an integrated understanding of the sea surface microlayer, Frontiers in Mararine Science, 4, 1-14, https://doi.org/10.3389/fmars.2017.00165, 2017.

Ferrari, G. M. and Dowell, M. D.: CDOM absorption characteristics with relation to fluorescence and salinity in coastal areas of the southern Baltic Sea, Estuar. Coast. Shelf S., 47, 91-105, https://doi.org/10.1006/ecss.1997.0309, 1998.

Frew, N., Goldman, J. C., Dennett, M. R., and Johnson, A. S.: Impact of phytoplankton-generated surfactants on airsea gas exchange, J. Geophys. Res.-Ocean., 95, 3337-3352, https://doi.org/10.1029/JC095iC03p03337, 1990.

Frew, N. M., Houghton, L. A., and Witzell Jr., W. E.: Variability of surface film distributions in a coastal ocean regime, in 16th Symposium on Boundary Layers and Turbulence and the Coupled Boundary Layer Air-Sea Transfer Experiment 8.7, http://ams.confex.com/ams/BLTAIRSE/techprogram/paper_ 78749.htm, last access: 12 August 2004.

Fuentes, M., Gonzalez-Gaitano, G., and Garcia-Mina, J. M.: The usefulness of UV-visible and fluorescence spectroscopies to study the chemical nature of humic substances from soils and composts, in: Organic Geochemistry, Elsevier Science B.V., Amsterdam, 37, 1949-1959, 2006.

Garrett, W. D.: Collection of slick-forming materials from the sea surface, Limnol. Oceanogr., 10, 602-605, https://doi.org/10.4319/lo.1965.10.4.0602, 1965.

Glatzel, S., Kalbitz, K., Dalva, M., and Moore, T.: Dissolved organic matter properties and their relationship to carbon dioxide efflux from restored peat bogs, Geoderma, 113, 397-411; https://doi.org/10.1016/S0016-7061(02)00372-5, 2003.

Guéguen, C., Guo, L., Yamamoto-Kawai, M., and Tanaka, N.: Colored dissolved organic matter dynamics across the shelf/basin interfaces in the western Arctic Ocean, J. Geophys. Res.-Ocean., 112, C05038, https://doi.org/10.1029/2006JC003584, 2007. 
Helms, J. R., Stubbins, A., Ritchie, J. D., Minor, E. C., Kieber, D. J., and Mopper, K.: Absorption spectral slopes and slope ratios as indicators of molecular weight, source, and photobleaching of chromophoric dissolved organic matter, Limnol. Oceanogr., 53, 955-969, https://doi.org/10.4319/lo.2008.53.3.0955, 2008

Hudson, N., Baker, A., and Reynolds, D.: Fluorescence analysis of dissolved organic matter in natural, waste and polluted waters - a review, River Res. Appl., 23, 631-649, https://doi.org/10.1002/rra.1005, 2007.

Huguet, A., Vacher, L., Relexans, S., Saubusse, S., Froidefond, J. M., and Parlanti, E.: Properties of fluorescent dissolved organic matter in the Gironde Estuary, Org. Geochem., 40, 706-719, https://doi.org/10.1016/j.orggeochem.2009.03.002, 2009.

Ishii, S. K. L. and Boyer, T. H.: Behavior of reoccurring parafac components in fluorescent dissolved organic matter in natural and engineered systems: A critical review, Environ. Sc. Technol., 46, 2006-2017, https://doi.org/10.1021/es2043504, 2012.

Jørgensen, L., Stedmon, C. A., Kragh, T., Markager, S., Middelboe, M., and Søndergaardv, M.: Global trends in the fluorescence characteristics and distribution of marine dissolved organic matter, Mar. Chem., 126, 139-148, https://doi.org/10.1016/j.marchem.2011.05.002, 2011.

Konik, M. and Bradtke, K.: Object-oriented approach to oil spill detection using ENVISAT ASAR images, ISPRS J. Photogramm., 118, 37-52, https://doi.org/10.1016/j.isprsjprs.2016.04.006, 2016.

Kowalczuk, P.: Seasonal variability of yellow substance absorption in the surface layer of the Baltic Sea, J. Geophys. Res.-Ocean., 104, 30047-30058, https://doi.org/10.1029/1999JC900198, 1999.

Kowalczuk, P., Ston-Egiert, J., Cooper, W. J., Whitehead, R. F., and Durako, M. J.: Characterization of chromophoric dissolved organic matter (CDOM) in the Baltic Sea by excitation emission matrix fluorescence spectroscopy, Mar. Chem., 96, 273-292, https://doi.org/10.1016/j.marchem.2005.03.002, 2005.

Kowalczuk, P., Stedmon, C. A., and Markager, S.: Modelling abso rption by CDOM in the Baltic Sea from season, salinity and chlorophyll, Mar. Chem., 101, 1-11, https://doi.org/10.1016/j.marchem.2005.12.005, 2006.

Kowalczuk, P., Durako, M. J., Young, H., Kahn, A. E., Cooper, W. J., and Gonsior, M.: Characterization of dissolved organic matter fluorescence in the South Atlantic Bight with use of PARAFAC model: Interannual variability, Mar. Chem., 113, 182-196, https://doi.org/10.1016/j.marchem.2009.01.015, 2009.

Kowalczuk, P., Zabłocka, M., Sagan, S., and Kuliński, K.: Fluorescence measured in situ as a proxy of CDOM absorption and DOC concentration in the Baltic Sea, Oceanologia, 52, 431-471, 2010.

Kuznetsova, M. and Lee, C.: Enhanced extracellular enzymatic peptide hydrolysis in the sea-surface microlayer, Mar. Chem., 73, 319-332, https://doi.org/10.1016/S0304-4203(00)00116-X, 2001.

Lakowicz, J. R.: Principles of fluorescence spectroscopy, 3rd Edn., Plenum Press, New York, 2006.

Leppäranta, M. and Myrberg, K.: Physical Oceanography of the Baltic Sea, Springer-Praxis, Heidelberg, Germany, 336 pp., 2009.

Liss, P. S. and Duce, R. A.: The sea surface and global change, Cambridge University Press, 2005.

Liss P. S., Watson, A. J., Bock, E. J., Jahne, B., Asher, W. E., Frew, N. M., Hasse, L., Korenowski, G. M., Merlivat, L., Phillips, L. F.,
Schlussel, P., and Woolf, D. K.: Report Group I - Physical processes in the microlayer and the air-sea exchange of trace gases, in: The Sea Surface and Global Change, edited by: Liss, P. S. and Duce, R. A., Cambridge University Press, UK, 1-34, 1997.

Loiselle, S. A., Bracchini, L., Dattilo, A. M., Ricci, M., Tognazzi, A., Cózar, A., and Rossi, C.: The optical characterization of chromophoric dissolved organic matter using wavelength distribution of absorption spectral slopes, Limnol. Oceanogr., 54, 590-597, https://doi.org/10.4319/lo.2009.54.2.0590, 2009.

Maciejewska, A. and Pempkowiak, J.: DOC and POC in the southern Baltic Sea, Part II - Evaluation of factors affecting organic matter concentrations using multivariate statistical methods, Oceanologia, 57, 168-176, https://doi.org/10.5697/oc.563.523, 2015.

McKnight, D. M., Harnisch, R., Wershaw, L., Baron, J. S., and Schiff, S.: Chemical characteristics of particulate, colloidal, and dissolved organic matter in Loch Vale Watershed, Rocky Mountain National Park, Biogeochemistry, 36, 99-214, https://doi.org/10.1023/A:1005783812730, 1997.

McKnight, D. M., Boyer, E. W., Westerhoff, P. K., Doran, P. T., Kulbe, T., and Andersen, D. T.: Spectrofluorometric characterization of dissolved organic matter for indication of precursor of organic material and aromaticity, Limnol. Oceanogr., 46, 38-48, https://doi.org/10.4319/lo.2001.46.1.0038, 2001.

Milori, D., Martin-Neto, L., Bayer, C., Mielniczuk, J., and Vagnato, V.: Humification degree of soil humic acids determined by fluorescence spectroscopy, Soil Sci., 167, 739-749; https://doi.org/10.1097/00010694-200211000-00004, 2002.

Mopper, K. and Schultz, C. A.: Fluorescence as a possible tool for studying the nature and water column distribution of DOC components, Mar. Chem., 41, 229-238, https://doi.org/10.1016/0304-4203(93)90124-7, 1993.

Moran, M. A., Sheldon Jr., W. M., and Zepp, R. G.: Carbon loss and optical property changes during long-term photochemical and biological degradation of estuarine dissolved organic matter, Limnol. Oceanogr., 45, 1254-1264, https://doi.org/10.4319/lo.2000.45.6.1254, 2000.

Murphy, K. R., Butler, K. D., Spencer, R. G. M., Stedmon, C. A., Boehme, J. R., and Aiken, G. R.: Measurement of dissolved organic matter fluorescence in aquatic environments: an interlaboratory comparison, Environ. Sc. Technol., 44, 9405-9412, https://doi.org/10.1021/es102362t, 2010.

Nelson, N. B. and Siegel, D. A.: The global distribution and dynamics of chromophoric dissolved organic matter, Annu. Rev. Mar. Sci., 5, 447-476, https://doi.org/10.1146/annurev-marine120710-100751, 2013.

Nightingale, P. D., Liss, P. S., and Schlosser, P.: Measurements of air-sea gas transfer during an open ocean algal bloom, Geophys. Res. Lett., 27, 2117-2120, https://doi.org/10.1029/2000GL011541, 2000.

Osburn, M., Sessions, A., and Spear, J.: Hydrogen-isotopic variability in fatty acids from Yellowstone National Park hot spring microbial communities, Geochim. Cosmochim. Ac., 75, 48304845, https://doi.org/10.1016/j.gca.2011.05.038, 2011.

Ostrowska, M., Darecki, M., Krężel, A., Ficek, D., and Furmańczyk, K.: Practical applicability and preliminary results of the Baltic Environmental Satellite Remote Sensing System (SatBałtyk), Polish Maritime Research, ISSN 1233-2585, 3, 22, 4349, 2015. 
Parlanti, E., Worz, K., Geoffroy, L., and Lamotte, M.: Dissolved organic matter fluorescence spectroscopy as a tool to estimate biological activity in a coastal zone submitted to anthropogenic inputs, Org. Geochem., 31, 1765-1781, https://doi.org/10.1016/S0146-6380(00)00124-8, 2000.

Pastuszak, M., Stålnacke, P., Pawlikowski, K., and Witek, Z.: Response of Polish rivers (Vistula, Oder) to reduced pressure from point sources and agriculture during the transition period (1988-2008), J. Marine Syst., 94, 157-173, https://doi.org/10.1016/j.jmarsys.2011.11.017, 2012.

Pereira, R., Schneider-Zapp, K., and Upstill-Goddard, R. C.: Surfactant control of gas transfer velocity along an offshore coastal transect: results from a laboratory gas exchange tank, Biogeosciences, 13, 3981-3989, 2016 https://doi.org/10.5194/bg-133981-2016, 2016.

Petelski, T., Markuszewski, P., Makuch, P., Jankowski, A., and Rozwadowska, A.: Studies of vertical coarse aerosol fluxes in the boundary layer over the Baltic Sea, Oceanologia, 56, 697710, https://doi.org/10.5697/oc.56-4.697, 2014.

Peuravouri, J. and Pihlaja, K.: Molecular size distribution and spectroscopic properties of aquatic humic substances, Anal. Chim. Acta, 337, 133-149, 1997.

Sabbaghzadeh, B., Upstill-Goddard, R. C., Beale, R., Pereira, R., and Nightingale, P. D.: The Atlantic Ocean surface microlayer from $50^{\circ} \mathrm{N}$ to $50^{\circ} \mathrm{S}$ is ubiquitously enriched in surfactants at wind speeds up to $13 \mathrm{~ms}^{-1}$, Geophys. Res. Lett., 44, 2852-2858, https://doi.org/10.1002/2017GL072988, 2017.

Santos, A. L., Oliveira, V., Baptista, L., Henriques, L., Gomes, N. C. M., and Almeida, A.: Effects of UV-B radiation on the structural and physiological diversity of bacterioneuston and bacterioplankton, Appl. Environ. Microb., 78, 2066, https://doi.org/10.1128/AEM.06344-11, 2012.

Sarpal, R. S., Mopper, K., and Keiber, D. J.: Absorbance properties of dissolved organic matter in Antarctic sea water, Antarc. J., 30, 139-140, 1995.

Soloviev, A. and Lukas, R.: Near-surface layer of the ocean, Structure, dynamics and applications, Springer, 2006.

Stedmon, C. A. and Bro, R.: Characterizing dissolved organic matter fluorescence with parallel factor analysis: a tutorial, Limnol. Oceanogr.-Meth., 6, 572-579, 2008.

Stedmon, C. A. and Markager, S.: Tracing the production and degradation of matter by fluorescence analysis autochthonous fractions of dissolved organic, Limnol. Oceanogr., 50, 1415-1426, https://doi.org/10.4319/lo.2005.50.5.1415, 2005.

Stedmon, C. A. and Nelson, N. B.: The optical properties of DOM in the ocean, in: Biogeochemistry of Marine Dissolved Organic Matter, 2nd Ed., Hansell, edited by: D. A. and Carlson, C. A., Elsevier Science, 481-508, 2015.

Stedmon, C. A., Markager, S., and Kaas, H.: Optical properties and signatures of chromophoric dissolved organic matter (CDOM) in Danish coastal waters, Estuar. Coast. Shelf. S., 51, 267-278, https://doi.org/10.1006/ecss.2000.0645, 2000.

Stedmon, C. A., S. Markager, S., and Bro, R.: Tracing dissolved organic matter in aquatic environments using a new approach to fluorescence spectroscopy, Mar. Chem., 82, 239-254, https://doi.org/10.1016/S0304-4203(03)00072-0, 2003.

Summers, R. S., Cornel, P. K., and Roberts, P. V.: Molecular size distribution and spectroscopic characterization of humic substances, Sci. Total. Environ., 62, 27-37, 1987.
Tilstone, G. H., Airs, R. L., Martinez-Vicente, V., Widdicombe, C., and Llewellyn, C.: High concentrations of mycosporine-like amino acids and colored dissolved organic matter in the sea surface microlayer off the Iberian Peninsula, Limnol. Oceanogr., 55, 1835-1850, https://doi.org/10.4319/lo.2010.55.5.183, 2010.

Timko, S., Maydanov, A., Pittelli, S. L., Conte, M. H., Cooper, W. J., Koch, B. P., Schmitt-Kopplin, P., and Gonsior, M.: Depth-dependent photodegradation of marine dissolved organic matter, Frontiers in Marine Sciences, 2, 1-13, https://doi.org/10.3389/fmars.2015.00066, 2015.

Twardowski, M. S. and Donaghay, P. L.: Separating in situ and terrigenous sources of absorption by dissolved materials in coastal waters, J. Gephys. Res., 106, 2545-2560, https://doi.org/10.1029/1999JC000039, 2001.

Uścinowicz, S.: Geochemistry of Baltic Sea, Surface sediments, edited by: Uścinowicz, S., PIG-PIB, Warsaw, 2011.

Vähätalo, A. V. and Wentzel, R. G.: Photochemical and microbial decomposition of chromophoric dissolved organic matter during long (months-years) exposition, Mar. Chem., 89, 313-326, https://doi.org/10.4319/lo.2008.53.4.1387, 2004.

Vaishaya, A., Jennings, S. G., and O'Dowd, C.: Wind-driven influences on aerosol light scattering in north-east Atlantic air, Geoph. Res. Lett., 39, L05805, https://doi.org/10.1029/2011GL050556, 2012.

Vodacek, A., Blough, N. V., DeGrandpre, M. D., Peltzer, E. T., and Nelson, R. K.: Seasonal variation of CDOM and DOC in the Middle Atlantic Bight: terrestrial inputs and photooxidation, Limnol. Oceanogr., 42, 674-686, https://doi.org/10.4319/lo.1997.42.4.0674, 1997.

Williams, C. J., Yamashita, Y., Wilson, H. F., Jaffé, R., and Xenopoulos, M. A.: Unraveling the role of land use and microbial activity in shaping dissolved organic matter characteristics in stream ecosystems, Limnol. Oceanogr., 55, 1159-1171, https://doi.org/10.4319/lo.2010.55.3.1159, 2010.

Williams, P. M., Carlucci, A. F., Henrichs, S. M., van Vleet, E. S., Horrigan, G. G., Reid, F. M. H., and Robertson, K. J.: Chemical and microbiological studies of sea-surface films in the southern Gulf of California and off the west coast of Baja California, Mar. Chem., 19, 17-98, https://doi.org/10.1016/0304-4203(86)900332, 1986.

Wilson, H. F. and Xenopoulos, M. A.: Effects of agricultural land use on the composition of fluvial dissolved organic matter, Nat. Geosci., 2, 37-41, https://doi.org/10.1038/NGEO391, 2009.

Wurl, O., Miller, L., Rottgers, R., and Vagle, S.: The distribution and fate of surface-active substances in the seasurface microlayer and water column, Mar. Chem., 115, 1-9, https://doi.org/10.1016/j.marchem.2009.04.007, 2009.

Yamashita, Y., Jaffé, R., Maie, N., and Tanoue, E.: Assessing the dynamics of dissolved organic matter (DOM) in coastal environments by excitation emission matrix fluorescence and parallel factor analysis (EEM-PARAFAC), Limnol. Oceanogr, 53, 1900 1908, https://doi.org/10.4319/lo.2008.53.5.1900, 2008.

Ylöstalo, P., Seppälä, J., Kaitala, S., Maunula, P., and Simis, S.: Loadings of dissolved organic matter and nutrients from the Neva River into the Gulf of Finland - Biogeochemical composition and spatial distribution within the salinity gradient, Mar. Chem., 186, 58-71, https://doi.org/10.1016/j.marchem.2016.07.004, 2016. 
Zhang, Y., van Dijk, M. A., Liu, M., Zhu, G., and Qin, B.: The contribution of phytoplankton degradation to chromophoric dissolved organic matter (CDOM) in eutrophic shallow lakes: Field and experimental evidence, Water Res., 43, 4685-4697, https://doi.org/10.1016/j.watres.2009.07.024, 2009.

Zhang, Y., Liu, X., Osburn, C. L., Wang, M., Qin, B., and Zhou, Y.: Photobleaching response of different sources of chromophoric dissolved organic matter exposed to natural solar radiation using absorption and excitation-emission matrix spectra, PLOS ONE, 8, e77515, https://doi.org/10.1371/journal.pone.0077515, 2013.
Zsolnay, A.: Dissolved organic matter: artefacts, definitions and functions, Geoderma, 113, 187-209, https://doi.org/10.1016/S0016-7061(02)00361-0, 2003.

Zsolnay, A., Baigar, E., Jimnez, M., Steinweg, B., and Saccomandi, F.: Differentiating with fluorescence spectroscopy the sources of dissolved organic matter in soils subjected to drying, Chemosphere, 38, 45-50, https://doi.org/10.1016/S00456535(98)00166-0, 1999. 